4. Madhukar P. Tracking TB Vaccination Policies and Practices Through Space and Time, available at: Https://Naturemicrobiology community.nature.com/posts/15729-tracking-tb-vaccination-policies-andpractices-through-space-and-time

5. On changes to the preventive vaccinations schedule in Ukraine. Order of Ministry of Health care in Ukraine (№947, 18.05.2018), available at: https://moz.gov.ua/article/ministry-mandates/nakaz-moz-ukraini-vid18052018--947-pro-vnesennja-zmin-do-kalendarja-profilaktichnihscheplen-v-ukraini [in ukr.]

6. Ustynov A.V. Tuberculosis in Ukraine: the incidence rate is declining, available at: https://www.umj.com.ua/article/139407/tuberkuloz-vukrayini-riven- zahvoryuvanosti-znizhuyetsya [in ukt.].

DOI https://doi.org/10.30525/978-9934-588-81-5-2.24

\title{
АСПЕКТИ ДОСЛІДЖЕННЯ CALTHA PALUSTRIS
}

\author{
Лях В. P. \\ аспірант кафедри технологї біологічно активних сполук, \\ фармаиії та біотехнології \\ Національний університет «Львівська політехніка»
}

Конечна Р. T.

кандидат фармацевтичних наук,

дочент кафедри технології біологічно активних сполук, фармачії та біотехнологї

Національний університет «Львівська політехніка»

Новіков В. П.

доктор хімічних наук,

завідувач кафедри технологї біологічно активних сполук, фармачії та біотехнології

Національний університет «Львівська політехніка» м. Львів, Украӥна

Калюжниця болотна (Caltha palustris) - це багаторічна трав'яниста рослина, що використовується як декоративна, харчова та лікарська рослина.

Caltha palustris поширена у всіх високогірних районах Українських Карпат. Росте на берегах водойм, вологих луках, озерах, заболо- 
чених лісах, по болотах, вздовж річок у повільно текучих та стоячих водах. У лікарських цілях використовують всю надземну частину рослини, яку збирають весною під час цвітіння [1].

Caltha palustris містить біологічно активні речовини як первинного так і вторинного синтезу. До ії складу входять алкалоїди, сапоніни, $\gamma$ лактони: протоанемонін, анемонін, дубильні речовини $(8,1 \%)$, аскорбінова кислота (37мг\%) . Усі частини рослини містять тритерпеноїди (палюстролід, калтолід, епікалтолід, 16,17-дигідроксикауронову-19 і хедерагенову кислоти), стероїди (ситостерин), каротиноїди(3епілутеїн), кумарини (скополетин, умбелліферон).

У підземних органах виявлено гетероциклічні з'єднання гелеборину. Квіти містять флавоноїди - кемпферол, кверцетин, 7-рамнозид, 3-глюкозид та 3-глюкозидо-7-рамнозид кемпферолу, 7-рамнозид, 3-глюкозид, 3-глюкозидо-7-рамнозид кверцетину. В насінні наявні алкалоїди, олії та вітамін С.

Сировину Caltha palustris здавна використовували в народній медицині різних народів. На сьогодні сировина Caltha palustris часто застосовується в гомеопатії у складі комплексних препаратів [2]. Доцільним $є$ комплексне дослідження рослини та впровадження іiї в фармацевтичну практику.

Метою наших досліджень було підтвердити наявність та визначити кількісний вміст флавоноїдів у сировині Caltha palustris а також встановити перспективу використання Caltha palustris у фармації та медицині.

Лікарську рослинну сировину заготовляли в екологічно чистих районах західної України влітку 2019 року. Сушили та стандартизували відповідно до вимог ДФУ. Екстракти Caltha palustris одержували методом екстракції в апараті Сокслета. Як екстрагент використовували водно-етанольні розчини в концентраціях 20\% (екстракт ЕК1), 40\% (екстракт ЕК2), 70\% (екстракт ЕК3) та 90\% (екстракт ЕК4) [1].

Загальний вміст флавоноїдів визначали спектрофотометричним методом. На першому етапі готували стандартний розчин кверцетину в концентраціях від 0,05 мкл до 2,2 мкл. До кожного розведення стандартного розчину кверцетину різної концентрації додавали 5\% розчин $\mathrm{NaNO}_{2}$, залишали на 5 хв, після чого додавали $10 \%$ розчин $\mathrm{AlCl}_{3}$ та $1 \mathrm{M}$ розчин $\mathrm{NaOH}, 96 \%$ етиловий спирт. Оптичну густину вимірювали при довжині хвилі 520 нм на спектрофотометрі Specord M 40. Аналогічно готували розчини досліджуваних екстрактів. Дослідження проводили при кімнатній температурі [3, 4]. 
В результаті проведеного дослідження, відповідно до одержаних даних будували стандартну криву (рис. 1). Розрахунки проводили за наступним рівнянням, виходячи зі стандартної кривої $y=0,02387 x+0,12387$.

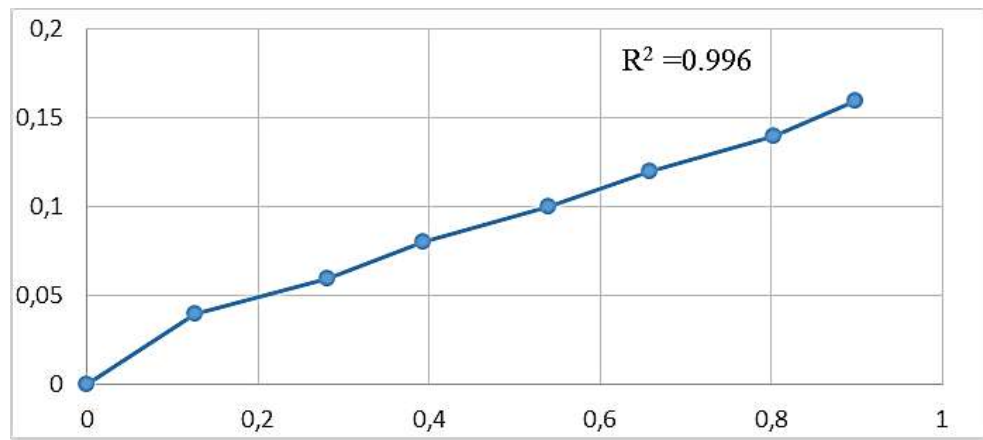

\section{Рис 1. Крива співвідношення концентрації кверцетину до оптичної густини}

На наступному етапі проводили визначення кількісного вмісту флавоноїдів у досліджуваних екстрактах. Для достовірності отриманих даних проводили 3-ох кратне вимірювання. Результати оброблено статистично та представлено в Таблиці 1.

Сума флавоноїдів в перерахунку на кверцетин в досліджуваних об'єктах

Таблиця 1

\begin{tabular}{|c|c|c|}
\hline Об'єкт & $\begin{array}{c}\text { Середнс значення } \\
\text { оптичної густини }\end{array}$ & $\begin{array}{c}\text { Перерахунок } \\
\text { на кверцетин, \%, } \\
\boldsymbol{x} \pm \boldsymbol{\Delta} \boldsymbol{x}, \boldsymbol{n = 3}\end{array}$ \\
\hline EК1 & 0,7815 & 0,1425 \\
\hline EК2 & 0,3628 & 0,1325 \\
\hline EК3 & 0,5028 & 0,1358 \\
\hline EK4 & 0,2221 & 0,1291 \\
\hline
\end{tabular}

Методом спектрофотометрії було визначено кількісний вміст флавоноїдів у екстрактах трави Caltha palustris та встановлено, що найбільший вміст флавоноїдів встановлено в екстрактах ЕК1 (екстрагент $20 \%$ водно-етанольний розчин. Проведене дослідження може бути 
використане при розробці методик контролю якості лікарської рослинної сировини та при створенні нових фітозасобів.

Наступним атапом дослідження було прогнозування екологічної токсичності Caltha palustris за допомогою програми GUSAR[5]. Програмне забезпечення GUSAR було розроблено для створення моделей QSAR / QSPR на основі відповідних навчальних наборів, представлених як SDfile, що містять дані про хімічні структури та кінцеві показники в кількісному вираженні.

Моделі QSAR були розроблені для наступних кінцевих точок:

- фактор біоконцентрації Log10(BCF)

- 48-год Daphnia magna $\mathrm{LC}_{50}-\log 10(\mathrm{~mol} / \mathrm{L})$,

- 96-год Fathead Minnow LC50 Log10(mmol/L)

- Tetrahymena pyriformis Daphnia magna LC50 -Log10(mol/L)

Для прогнозування обрано наступні біологічно активні речовини Caltha palustris: анемонін, протоанемонін, палюстролід,калтолід, 16,17-дигідроксикауронова кислота, хедерагенова кислота, ситостерин, скополетин, умбеліферон.

Отримані результати показали, що вибрані сполуки не випадають iз моделі QSAR / QSPR, i тому прогнозування за допомогою програми GUSAR $є$ можливе. Результати екологічної токсичності обраних речовин наведено в таблиці 2.

Таблиця 2

\begin{tabular}{|c|c|c|c|c|}
\hline $\begin{array}{c}\text { Назва } \\
\text { речовини }\end{array}$ & $\begin{array}{c}\text { Фактор біо- } \\
\text { концентраціï } \\
\text { Log10(BCF) }\end{array}$ & $\begin{array}{c}\text { Daphnia } \\
\text { magna } \\
\text { LC50 - } \\
\text { Log10(mol/L) }\end{array}$ & $\begin{array}{c}\text { Fathead } \\
\text { Minnow LC50 } \\
\text { Log10(mmol/L) }\end{array}$ & $\begin{array}{c}\text { Tetrahymena } \\
\text { pyriformis } \\
\text { IGC50 - } \\
\text { Log10(mol/L) }\end{array}$ \\
\hline Протоанемонін & 0,548 & 3,960 & $-0,563$ & $-0,146$ \\
\hline Анемонін & 0,639 & 3,514 & $-0,135$ & $-0,207$ \\
\hline Палюстролід & 2,046 & 4,569 & $-1,571$ & 0,793 \\
\hline Калтолід & 1,733 & 5,737 & $-4,131$ & 1,442 \\
\hline $\begin{array}{c}16,17- \\
\text { дигідроксикау- } \\
\text { ронова кислота }\end{array}$ & 0,933 & 4,660 & $-1,891$ & 0,887 \\
\hline $\begin{array}{c}\text { Хедерагенова } \\
\text { кислота }\end{array}$ & 1,078 & 5,509 & $-4,073$ & 1,104 \\
\hline Ситостерин & 2,257 & 5,742 & $-5,163$ & 2,267 \\
\hline Скополетин & 0,583 & 4,881 & $-0,767$ & 0,351 \\
\hline Умбеліферон & 0,636 & 4,491 & $-0,715$ & 0,504 \\
\hline
\end{tabular}

Враховуючи хімічний склад рослини, досвід використання ії в народній медицині різних народів та незначний досвіт застосування іiі фармацевтичною промисловістю, слід зробити висновок про перспек- 
тиви використання рослинної сировини Caltha palustris для більш детального фітохімічного та фармакологічного дослідження з метою подальшого створення косметичних, лікарських та лікувальнопрофілактичних засобів на ії основі.

\title{
Література:
}

1. Нестерук Ю. Рослинний світ Українських Карпат. Чорногора. Екологічні мандрівки - Львів, 2013. С. 122-123.

2. Гродзінський А.М. Лікарські рослини: Енциклопедичний довідник - Москва, 2009. С. 480-481.

3. Angkawijaya, P.L. Tran-Nguyen [et al] . Effect of extraction solvent on total phenol content, total flavonoid content, and antioxidant activity of Limnophila aromatica . Journal of Food and Drug Analysis. - 2014. № 22. P. 296-302.

4. Sumaiyah, Masfria and A. Dalimunthe. Determination of total phenolic content, total flavonoid content, and antimutagenic activity of ethanol extract nanoparticles of rhaphidophora pinnata (L.f) schott leaves. Rasayan Journal of Chemistry. - 2018. № (2). P. 505-510

5. Програма GUSAR : http://www.way2drug.com/gusar/

DOI https://doi.org/10.30525/978-9934-588-81-5-2.25

\section{ІННОВАЦІЇ ЯК СКЛАДОВА СВРОПЕЙСЬКИХ СТАНДАРТІВ ПРИ НАВЧАННІ ПРОВІЗОРІВ}

\author{
Маслак Г. С. \\ доктор біологічних наук, доцент, \\ завідувач кафедри біохімії та медичної хімії \\ Державний заклад "Дніпровська медична академія \\ Міністерства охорони здоров'я України» \\ Хмельникова Л. І. \\ кандидат хімічних наук, \\ дочент кафедри біохімії та медичної хімії \\ Державний заклад "Дніпровська медична академія \\ Міністерства охорони здоров'я Украӥни» \\ м. Дніпро, Україна
}

Впровадження інновацій в навчальний процес підвищує успішність, мотивацію студентів, стимулює компенсацію обмеженого простору аудиторії [1, с. 124]. 